\title{
SKENARIO PENGELOLAAN KEPESISIRAN BERKELANJUTAN KABUPATEN BUTON SELATAN, PROVINSI SULAWESI TENGGARA
}

\author{
La Ode Alisyukur ${ }^{1 *}$, Sunarto $^{2)}$, Muh Aris Marfai ${ }^{2)}$ \\ ${ }^{1)}$ Mahasiswa Doktoral Ilmu Lingkungan, Sekolah Pascasarjana Universitas Gadjah Mada, Yogyakarta \\ ${ }^{2)}$ Geografi Lingkungan, Fakultas Geografi Universitas Gadjah Mada.
}

*Email: alisyukur06@gmail.com

\section{ABSTRACT \\ SCENARIOS FOR SUSTAINABLE COASTAL ZONE MANAGEMENT OF SOUTH BUTON REGENCY, SOUTH EAST SULAWESI PROVINCE}

The coastal zone of South Buton Regency consists of unique ecosystems and abundant natural resources, but facing problems, mainly in terms of conflict between economic needs and ecological aspects. This study aims to set up scenarios for sustainable coastal zone management (SCZM) in South Buton Regency that are synergistic and benefit all stakeholders, without disregarding the principals of ecological conservation. Data were collected by interviews and field observations and were analyzed using prospective analysis method. Comprehensive analyisis were performed encompassing the effects and interactions of key components of the successfulness of the SCZM in South Buton based on the stakeholders desires. Three environmental management scenarios were assessed, namely: the conservative-pessimistic scenario, in which refinements for the key components are at minimum levels, the moderate-optimistic scenario, in which refinements for the key components are about 50\%, and the progressive-optimistic scenario, in which all the key components are addressed for refinements. Results of the prospective analysis show that the moderate-optimistic scenario was the most appropriate scheme to be implemented for the sustainable coastal zone management in South Buton Regency, follows by progressiveoptimistic and conservative-pessimistic scenarios, respectively.

Keywords: Coastal zone; Key components; Prospective analysis; Environmental management scenarios.

\section{PENDAHULUAN}

Kawasan pesisir (coastal zone) adalah perbatasan antara lautan dan daratan yang menjadi salah satu wilayah pilihan bagi sebagian penduduk dunia untuk bermukim dan mencari nafkah. Penduduk yang bermukin di kawasan pesisir diperkirakan mencapai $70 \%$ dari populasi dunia (MacDonald, 2005). Kemudahan transportasi perairan, ketersediaan sumber makanan dari hewan laut dan kemudahan untuk membuang limbah menjadi motivasi besar bagi manusia untuk bermukim di kawasan pesisir (Clark, 1997; Joseph \& Balchand, 2000);
MacDonald, 2005). Sementara, aktivitas manusia yang ada di wilayah pesisir dengan berbagai kepentingan dan penggunaan lahan yang kompleks, menjadikan wilayah tersebut sangat dinamis (Marfai \& King, 2008). Dinamika pemanfaatan kawasan pesisir berakibat pada penurunan daya dukung dan daya tampung kawasan tersebut. Oleh karena itu, upaya-upaya pengelolaan yang baik menjadi prioritas utama dalam pemanfaatan lahan pada kawasan tersebut.

Aktivitas manusia serta proses-proses alam pada kawasan pesisir berakibat pada dinamika perubahan garis pantai. Kecenderungan pertumbuhan populasi dan komplesitas kondisi sosial ekonomi 
berdampak pada kawasan pesisir, khususnya ekosistem alami pesisir (Xu et al., 2016). Ekosistem alami pesisir perlu dijaga keberlanjutannya, karena area ekologis kawasan pesisir rentan terhadap pengaruh lingkungan alam seperti terkena badai (Kantamaneni et al., 2018), penurunan muka tanah (Marfai \& King, 2007), kenaikan permukaan laut (Barbier, 2015), dan intrusi air asin (Uncles et al., 2018). Lebih jauh, kawasan pesisir sangat rentan terhadap gangguan antropogenik akibat dari aktivitas yang berlebihan (Fan et al., 2019; (Waluyo Sanchez-Cabez \& Druffel, 2009).

Pesisir merupakan wilayah penting dan strategis bagi negara-negara kepulauan, khususnya Indonesia, guna memperkuat perekonomian bangsa di masa yang akan datang. Zona Ekonomi Eksklusif (ZEE) Indonesia diberikan kewenangan penuh untuk mengelola sumberdaya alam yang ada di dalamnya serta dapat berperan dalam pemanfaatan di luar batas ZEE tersebut (Dahuri, 2001). Indonesia memiliki potensi sumberdaya kepesisiran dengan ekosistem yang unik, seperti terumbu karang, hutan bakau, dan lamun. Sebagai salah satu negara yang memiliki hamparan terumbu karang luas, Indonesia berkontribusi sekitar 18\% luas kawasan terumbu karang dunia dan sekitar $65 \%$ kawasan coral triangle ada di Indonesia (Roza, 2017). Luas terumbu karang di Indonesia adalah sekitar 75.000 $\mathrm{km}^{2}$, dimana sekitar $52 \%$ terdapat di perairan Indonesia Bagian Timur (Sudirman, 2008). Namun demikian, kondisi terumbu karang yang dikategorikan masih baik hanya sekitar $29,52 \%$, sementara sisanya tergolong rusak hingga kritis (Hadi et al, 2018). Selain keberadaan kawasan terumbu karang, Indonesia juga memiliki sumberdaya alam hutan bakau yang luas. Namun demikian, tutupan bakau yang ada di Indonesia telah berkurang hingga 50\% selama 30 tahun terakhir (Widyaningrum, 2019). Hutan bakau adalah ekosistem yang mengandung potensi sumberdaya dan bersifat dapat diperbaharui (renewable resources), namun kerusakannya tidak mudah dihentikan (Spalding et al., 2014)).
Kegiatan-kegiatan yang tidak terkendali di kawasan pesisir akibat pertambahan penduduk dan kebutuhan ekonomi telah menyebabkan degradasi lahan di kawasan tersebut. Perencanaan yang tidak komprehensif terhadap eksploitasi kawasan kepesisiran berakibat adanya konflik terhadap ruang serta sumber daya laut (Lee et al., 2014). Degradasi yang terjadi pada kawasan pesisir baik yang diakibatkan oleh ulah manusia (antropogenik) dan prosesproses alami maupun interaksi keduanya berimplikasi pada penurunan fungsi kawasan tersebut. Maka dari itu, instrumen kebijakan pengelolaan kawasan kepesisiran diperlukan untuk mensinergikan seluruh pemangku kepentingan (stakeholders) sehingga kegiatan-kegiatan ekonomi dapat berjalan namun tetap memperhatikan kelestarian kawasan tersebut. Strategi pembangunan dan industrialisasi berbasis sumberdaya alam kepesisiran yang berkelanjutan perlu dirancang, terutama dalam era otonomi daerah, guna menjamin keberlangsungan hidup masyarakat kepesisiran dengan mempertahankan kelestarian kawasan pesisir. Sumberdaya alam pada kawasan pesisir di Kabupaten Buton Selatan, seperti terumbu katang, hutan bakau, padang lamun dan habitat akuatik lainnya memiliki arti yang sangat penting bagi masyarakat setempat. Namun pengelolaan sumberdaya pada kawasan tersebut belum dilakukan secara optimal. Kegiatan-kegiatan pemanfaatan lahan secara ilegal, seperti kegiatan penambangan pasir pantai oleh masyarakat setempat berakibat pada berkurangnya tutupan bakau di kawasan pesisir Buton Selatan. Implikasi hilangnya tutupan bakau adalah menurunnya kualitas dan kuantitas keanekaragaman hayati (biodiversitas) ekosistem kepesisiran. Oleh karena itu, kebijakan yang berkelanjutan diperlukan terkait pengelolaan kawasan kepesisiran di Kabupaten Buton Selatan.

Perencanaan tata ruang kawasan kepesisiran perlu diintegrasikan dalam pengelolaan berkelanjutan untuk menjamin fungsi sumber daya alam kepesisiran. Perencanaan tersebut menjadi bagian dari 
sistem rekayasa pengelolaan sebagai dasar pembagian wilayah (zonasi) dalam pemanfaatan sumberdaya pada kawasan pesisir. Kawasan kepesisiran Buton Selatan memiliki ekosistem dengan komponenkomponen yang saling terkait. Implikasi keterkaitan antar komponen ekosistem adalah bahwa tidak berfungsinya salah satu komponen berakibat pada terganggunya komponen yang lain. Permasalahan lingkungan di wilayah kepesisiran Buton Selatan yang teridentifikasi pada komponen bio-fisik adalah semakin rusaknya habitat kepesisiran, perubahan penggunaan lahan dan tidak terkendalinya penambangan pesisir pantai. Permasalahanyang diidentifikasi pada komponen ekonomi adalah menurunnya pendapatan masyarakat pesisir akibat degradasi sumberdaya alam hayati. Selanjutnya, permasalahan pada komponen sosial-budaya pada dasarnya adalah turunan dari permasalahan komponen bio-fisik dan komponen ekonomi, yaitu tidak tersedianya lapangan kerja berdampak pada konflik di masyarakat.

Berdasarkan permasalahan wilayah kepesisiran yang telah diuraikan pada paragraf-paragraf sebelumnya, maka skenario-skenario pengelolaan wilayah kepesisiran berkelanjutan di Kabupaten Buton Selatan perlu dikaji. Skenarioskenario tersebut haruslah mengadaptasi kondisi ekosistem yang ada di wilayah tersebut. Kebijakan-kebijakan dalam pengelolaan lingkungan wilayah kepesisiran berkelanjutan di daerah diturunkan dari kebijakan nasional yaitu UU No.1/2014 (Pengelolaan wilayah pesisir dan pulaupulau kecil). Adaptasi kebijakan nasional dilakukan berdasarkan kondisi lingkungan lokal.

\section{METODOLOGI}

\subsection{Lokasi Kajian}

Kajian dilakukan pada dua kecamatan pesisir di Kabupaten Buton Selatan, Provinsi Sulawesi Tenggara, yaitu Kecamatan Sampolawa dan Kecamatan Batauga seperti ditunjukkan pada Gambar 1. Secara geografis wilayah kajian berada di antara $05^{\circ}$ $30^{\prime}-03^{\circ} 06^{\prime} \mathrm{LS}$ dan $122^{\circ} 30^{\prime}-123^{\circ} 00^{\prime} \mathrm{BT}$.

\subsection{Data}

Data dikumpulkan menggunakan metode observasi (survei lapangan), kuisioner serta diskusi dan wawancara langsung para pakar dan stakeholders secara purposive. Metode pengumpulan data ini melalui pertimbangan-pertimbangan yang berdasarkan pada kebutuhan peneliti. Sampel adalah beberapa pakar yang kompeten dalam bidang lingkungan perencanaan wilayah, seperti akademisi, birokrat dan lembaga swadaya masyarakat (LSM).

\subsection{Analisis}

Analisis keadaan dilakukan menggunakan analisis prospektif. Analisis prospektif bertujuan untuk mengkaji berbagai kemungkinan pengelolaan lingkungan wilayah kepesisiran berkelanjutan yang dapat diterapkan di Kabupaten Buton Selatan di masa mendatang. Analisis dilakukan dengan cara menentukan pengaruh komponen-komponen serta interaksi antar komponen dalam skenario keadaan yang dipilih. Komponen-komponen kunci yang ditentukan dalam penelitian ini mengacu dari Bourgeois \& Jesus (2004), yaitu komponen penentu (Input), komponen penghubung (stakes), komponen terkait (output), dan komponen bebas (unused).

Analisis prospektif dilakukan melalui tahapan berikut: (1) Penentuan komponenkomponen kunci skenario-skenario pengelolaan serta pengujian kemungkinan skenario-skenario tersebut di masa mendatang. Identifikasi dan analisis terhadap semua komponen dilakukan guna menunjukkan pengaruh komponen terhadap kinerja skenario serta keterkaitan antar komponen dalam tersebut. Tingkat keterkaitan antar komponen diberi nilai dari 0 hingga 3 , dengan 3 mengindikasikan keterkaitan yang sangat erat; (2) Penentuan tujuan skenario dan kepentingan stakeholders; (3) Pendefinisian dan 
pendeskripsian skenario yang mungkin dapat diterapkan pada masa mendatang. Alternatif panyusunan skenario pengelolaan wilayah kepesisiran Buton Selatan di masa mendatang ditentukan berdasarkan komponen-komponen yang berpengaruh terhadap skenario tersebut. Prospek komponen-komponen penting pada masa mendatang dimodel berdasarkan kategori keadaan seperti disajikan dalam Tabel 1. Skenario-skenario model pengelolaan yang diperoleh diharapkan dapat menjadi rekomendasi kebijakan pengelolaan kepesisiran berkelanjutan di Kabupaten Buton Selatan.

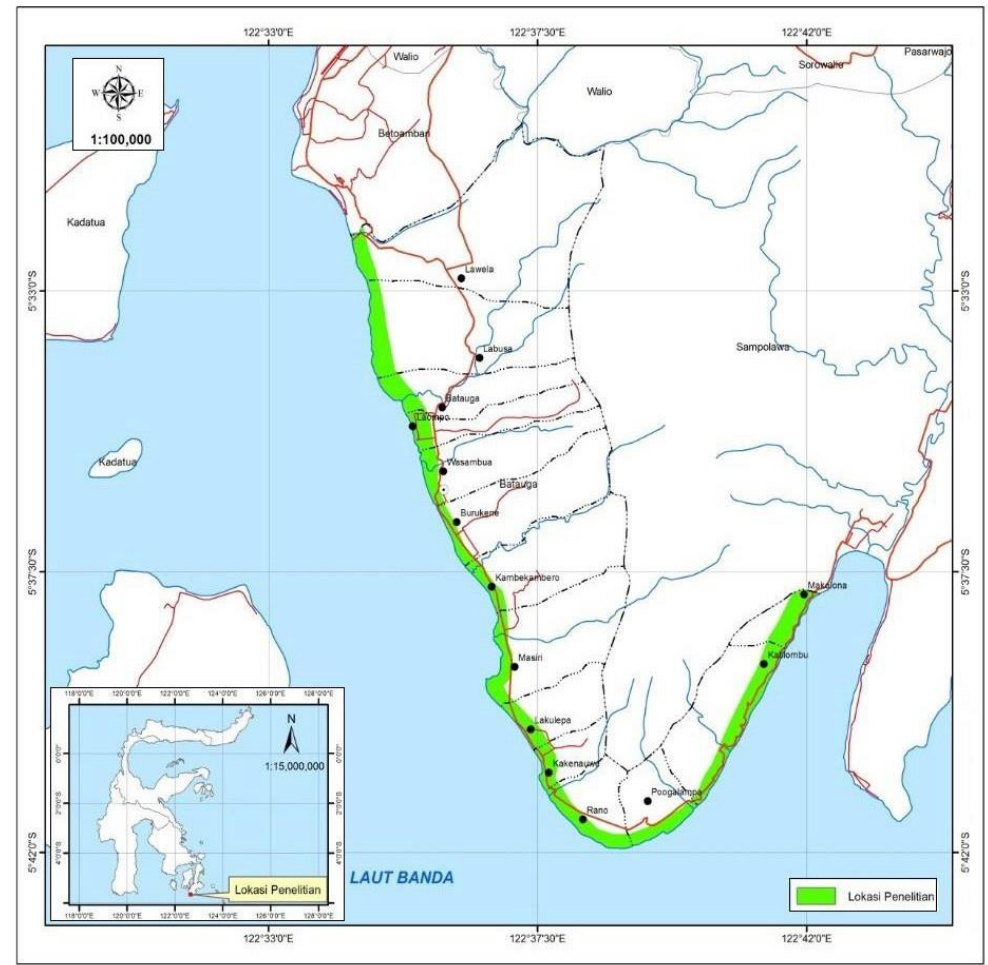

Gambar 1

Peta lokasi kajian

Tabel 1 Kategori keadaan terhadap komponen-komponen penting di masa depan pada pengelolaan kawasan kepesisiran Kab. Buton Selatan

\begin{tabular}{cccc}
\hline \multirow{2}{*}{ Komponen } & \multicolumn{3}{c}{ Kategori Keadaan } \\
\cline { 2 - 4 } & $\mathrm{R}$ & $\mathrm{S}$ & $\mathrm{T}$ \\
\hline 1 & $1(\mathrm{R})$ & $1(\mathrm{~S})$ & $1(\mathrm{~T})$ \\
2 & $2(\mathrm{R})$ & $2(\mathrm{~S})$ & $2(\mathrm{~T})$ \\
3 & $3(\mathrm{R})$ & $3(\mathrm{~S})$ & $3(\mathrm{~T})$ \\
$\mathrm{n}$ & $\mathrm{n}(\mathrm{R})$ & $\mathrm{n}(\mathrm{S})$ & $\mathrm{n}(\mathrm{T})$ \\
\hline
\end{tabular}

Ket: $n=$ jumlah komponen, $R=$ rendah, $S=$ sedang dan $T=$ tinggi. 


\section{HASIL DAN PEMBAHASAN}

\subsection{Prospektif Pengelolaan Wilayah Kepesisiran Buton Selatan}

Analisis awal dilakukan guna mengidentifikasi komponen-komponen kunci (key components) dan skenario pengelolaan kawasan kepesisiran di Kabupaten Buton Selatan sesuai dengan kebutuhan stakeholders. Berdasarkan hasil analisis keberlanjutan, diperoleh 15 komponen kunci yang berpengaruh kuat dalam skenario pengelolaan, seperti disajikan dalam Tabel 2.

Tabel 2. Komponen-komponen kunci dalam skenario pengelolaan kawasan kepesisiran berkelanjutan di Kabupaten Buton Selatan

\begin{tabular}{ll}
\hline No. & \multicolumn{1}{c}{ Komponen Kunci } \\
\hline 1. & Perlindungan fisik habitat \\
2. & Pariwisata \\
3. & Produktivitas industri perikanan \\
4. & Tingkat penguasaan teknologi \\
5. & Insentif investasi \\
6. & Pemberdayaan masyarakat dalam kegiatan \\
& perikanan \\
7. & Kelayakan usaha perikanan \\
8. & Ketersediaan industri pengolahan hasil \\
& perikanan \\
9. & Intensitas konversi lahan perikanan \\
10. & Mekanisme kerjasama lintas sektoral \\
11. & Kondisi sarana dan prasarana jalan
\end{tabular}

\begin{tabular}{ll}
\hline No. & Komponen Kunci \\
\hline 12. & Ketersediaan Basis Data Perikanan \\
13. & Penggunaan Teknologi dalam budidaya \\
14. & Peran masyarakat adat dalam kegiatan \\
15. & Kerjasama dengan swasta \\
\hline \multicolumn{2}{c}{ Sumber: Modifikasi penulis }
\end{tabular}

Berdasarkan analisis komponenkomponen pendukung keberhasilan pengelolaan wilayah kepesisiran di Kabupaten Buton Selatan, diperoleh indeks pengaruh seperti ditunjukkan pada Gambar 2 . Tiap kuadran dalam grafik (Gambar 2) mencirikan karakteristik dari variabel dalam skenario (Bourgeois \& Jesus, 2004). Kuadran 1 (kiri atas) merupakan area variabel penggerak (driving variabels) yang sebagian besar merupakan variabel terkuat dalam sistem. Variabel-variabel kunci yang berpengaruh kuat, namun memiliki tingkat ketergantungan antar variabel yang kurang kuat selanjutnya dijadikan sebagai masukan (inputs). Kuadran 2 (kanan atas) berkaitan dengan variabel-variabel penghubung (Stakes), baik influen maupun bebas. Beberapa dari variabel tersebut dapat dianggap sebagai variabel kuat. Kuadran 3 (kanan bawah) berisi variabel-variabel keluaran (outputs) yang sangat bergantung pada variabel lain dan berpengaruh kecil. Sementara, pada kuadran 4 (kiri bawah) mengandung variabel-variabel marginal atau variabel-variabel bebas yang berpengaruh kecil dan tingkat ketergantungannya pun rendah.

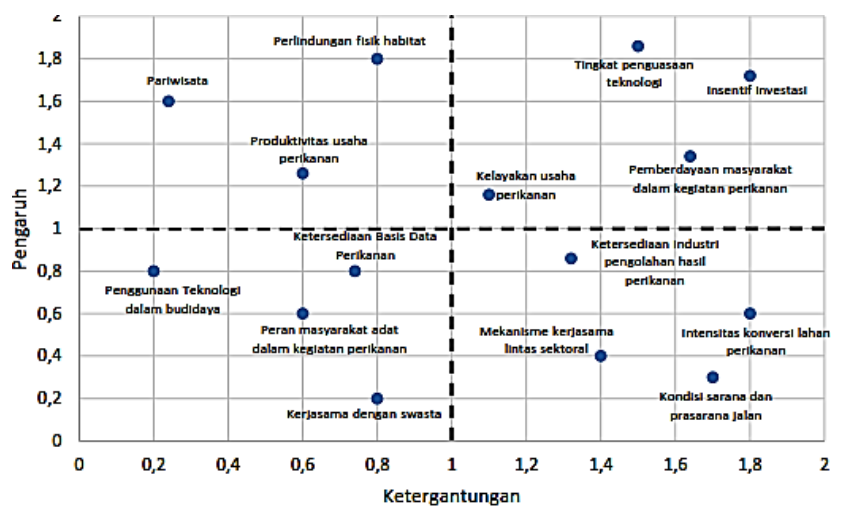

Gambar 2.

Pengaruh dan ketergantungan komponen-komponen kunci dalam skenario pengelolaan kawasan kepesisiran berkelanjutan di Kabupaten Buton Selatan 
Komponen-komponen kunci adalah indikator yang digunakan sebagai penilaian keberhasilan skenario. Pengaruh serta variasi ketergantungan antar komponen kunci sangat menentukan keberhasilan pengelolaan wilayah kepesisiran di Kabupaten Buton Selatan di masa mendatang. Hasil penentuan dari komponen-komponen kunci selanjutnya dijadikan dasar untuk menyusun skenario keadaan di masa mendatang. Keadaan setiap komponen kunci dan prospek pengelolaan wilayah kepesisiran berkelanjutan di Kab. Buton Selatan disajikan dalam Tabel 3.

Berdasarkan Tabel 3, terdapat indikasi bahwa keadaan-keadaan terjadi secara tidak bersamaan (mutual incompatible) atau bisa terjadi tetapi peluangnya sangat kecil. Sebagai contoh adalah produktifitas industri usaha perikanan yang peningkatannya bertahap sesuai dengan kemampuan petani tambak, namun peningkatan yang tinggi bahkan tidak terkendali terjadi pada intensitas konversi lahan.

\subsection{Skenario-skenario Pengelolaan}

Analisis 15 komponen kunci dalam skenario pengelolaam dilakukan untuk memperoleh pengaruh serta keterkaitan antar komponen-komponen tersebut terhadap kinerja skenario. Susunan dari 15 komponen kunci yang dianalisis dalam skenarioskenario pengelolaan kawasan kepesisiran di Kabupaten Buton Selatan disajikan dalam Tabel 4. Urutan komponen-komponen kunci pada tiap skenario disusun berdasarkan kemampuan serta kesiapan pemerintah daerah kabupaten untuk menerapkannya dalam jangka 5 tahun. Dalam penerapannya, skema pembagian waktu tersebut dibagi menjadi 3, yaitu durasi 1-2 tahun (jangka pendek), durasi 3-5 tahun (jangka menengah) dan durasi lebih dari 5 tahun (jangka panjang). Susunan keadaan komponenkomponen kunci pengelolaan dalam Tabel 4 menunjukkan sifat keadaan pada masa mendatang dari skenario yang dirancang, yaitu keadaan yang bersifat tetap seperti sekarang, konservatif-pesimistik, moderatoptimistik dan progresif-optimistik. 
Tabel 3. Keadaan setiap komponen kunci dan Prospek Pengelolaan Wilayah Kepesisiran Berkelanjutan Kabupaten Buton Selatan

\begin{tabular}{|c|c|c|c|}
\hline No & Komponen & & Keadaan \\
\hline \multirow[t]{2}{*}{1} & Perlindungan fisik habitat & $\mathbf{1}(\mathbf{R})$ & $\mathbf{1}(\mathbf{S})$ \\
\hline & & Tidak ada & Ada tapi tidak terpadu (bersifat \\
\hline \multirow[t]{2}{*}{2} & Pariwisata & $2(\mathbf{R})$ & $2(S)$ \\
\hline & & Tidak/belum ada & $\begin{array}{c}\text { Ada tapi tidak terpadu (bersifat } \\
\text { sektoral) }\end{array}$ \\
\hline \multirow[t]{2}{*}{3} & Produktivitas industri perikanan & $\mathbf{3}(\mathbf{R})$ & $\mathbf{3}(\mathbf{S})$ \\
\hline & & Kurang produktif & Produktif tapi peningkatannya lambat \\
\hline \multirow[t]{2}{*}{4} & Tingkat penguasaan teknologi & $4(R)$ & $4(S)$ \\
\hline & & $\begin{array}{l}\text { Rendah (tidak ada transfer } \\
\text { teknologi kepada masyarakat) }\end{array}$ & $\begin{array}{l}\text { Sedang (ada transfer teknologi namun } \\
\text { kemampuan tidak meningkat) }\end{array}$ \\
\hline \multirow[t]{2}{*}{5} & Insentif investasi & $\mathbf{5}(\mathbf{R})$ & $\mathbf{5}(\mathbf{S})$ \\
\hline & & Tidak ada & Ada tapi bersifat cost effective \\
\hline \multirow{2}{*}{6} & Pemberdayaan masyarakat dalam & $6(R)$ & $6(\mathbf{S})$ \\
\hline & kegiatan perikanan & Tidak ada & $\begin{array}{l}\text { Ada tapi untuk usaha-usaha perikanan } \\
\text { tertentu }\end{array}$ \\
\hline \multirow[t]{2}{*}{7} & $\begin{array}{l}\text { Kelayakan usaha } \\
\text { perikanan }\end{array}$ & $\mathbf{7}(\mathrm{R})$ & $\mathbf{7}(\mathrm{S})$ \\
\hline & & $\begin{array}{c}\text { Tidak layak (tidak menguntungkan } \\
\text { secara ekonomi) }\end{array}$ & $\begin{array}{c}\text { Kurang layak (upaya mandiri } \\
\text { masyarakat) }\end{array}$ \\
\hline \multirow[t]{2}{*}{8} & Ketersediaan industri pengolahan & $8(\mathbf{R})$ & $\mathbf{8}(\mathbf{S})$ \\
\hline & hasil perikanan & $\begin{array}{c}\text { Ada tapi teknologinya masih } \\
\text { sederhana }\end{array}$ & $\begin{array}{l}\text { Ada dan sudah melibatkan teknologi } \\
\text { sedang }\end{array}$ \\
\hline \multirow[t]{2}{*}{9} & Intensitas konversi lahan perikanan & $\mathbf{9}(\mathbf{R})$ & $9(\mathbf{S})$ \\
\hline & & Tinggi dan tidak terkontrol & Sedang \\
\hline
\end{tabular}

(T)

Ada dan terpadu (lintas sektoral)

2(T)

Ada dan terpadu (lintas sektoral)

3(T)

Produktif dan peningkatannya cepat

$$
\text { 4(T) }
$$

Tinggi (ada transfer teknologi serta mampu penguasaan teknologi terbaru)

\section{5(T)}

Ada dan bersifat cost effective

$$
\text { 6(T) }
$$

Ada untuk semua usaha perikanan

$$
\text { 7(T) }
$$

Layak (Ada pembinaan masyarakat)

\section{8(T)}

Ada dan melibatkan teknologi terbaru

Rendah (Ada kebijakan pemanfaatan lahan) 
Tabel 3 ...(Lanjutan)

10 Mekanisme kerjasama lintas sektoral

11 Kondisi sarana dan prasarana jala

12 Ketersediaan basis data perikanan

$12(\mathbf{R})$

Tidak ada

13(R)

Ada tapi teknologinya masih sederhana

14(R)

Tidak ada

15(R)

Tidak ada
10(S)

Ada tapi tidak efektif

11(S)

Meningkat tapi perbaikan hanya jalurjalur tertentu.

12(S)

Ada tapi tidak lengkap dan bersifat tertutup

13(S)

Ada dan sudah melibatkan teknologi sedang

14(S)

Ada tapi tidak melibatkan teknologi

15(S)

Ada namun tidak efektif
10(T)

Ada dan efektif

$11 \mathrm{~T}$

Meningkat dan perbaikan pada semua jalur (Kab, Kec, Desa, usahatani)

12(T)

Ada dan bersifat terbuka

13(T)

Ada dan melibatkan teknologi terbaru

14(T)

Ada dan melibatkan teknologi

15(T)

Ada dan efektif

Sumber: Hasil pengolahan data dan analisis 
Tabel 4. Hasil analisis prospektif skenario pengelolaan kawasan kepesisiran di Kab. Buton Selatan

\begin{tabular}{|c|c|c|}
\hline Skala & Skenario Pengelolaan & Susunan Keadaan Komponen \\
\hline 0 & Kondisi sekarang & $\begin{array}{l}\text { 1(S), 2(S), 3(S), 4(R), 5(R), 6(R), 7(T), 8(R), 9(R), } \\
\text { 10(R), 11(S), 12(R), 13(R),14(S), } 15(\mathrm{~S})\end{array}$ \\
\hline 1 & Konservatif-Pesimistik & $\begin{array}{l}\text { 1(S), 2(T), 3(S), 4(R), 5(S), 6(S), 7(T), 8(R), 9(S), } \\
\text { 10(R), 11(S), 12(R), 13(S),14(S), 15(S) }\end{array}$ \\
\hline 2 & Moderat-Optimistik & $\begin{array}{l}\text { 1(T), 2(S), 3(S), 4(S), 5(S), 6(S), 7(T), 8(S), 9(S), } \\
\text { 10(S), 11(T), 12(S), 13(T),14(S), 15(T) }\end{array}$ \\
\hline 3 & Progresif-Optimistik & $\begin{array}{l}\text { 1(T), 2(T), 3(T), 4(T), 5(S), 6(T), 7(T), 8(S), 9(T), } \\
\text { 10(S), 11(T), 12(T), 13(S),14(T), 15(T) }\end{array}$ \\
\hline
\end{tabular}

Sumber: Hasil pengolahan data dan analisis

Kondisi kawasan pesisir saat ini menunjukkan pengelolaan komponen ekologi bersifat kurang berkelanjutan. Pengelolaan komponen-komponen ekonomi, sosial-budaya serta komponen institusional dan tata aturan cukup prospek. Sementara, komponen sarana dan prasarana bersifat tidak mengalami perubahan. Dengan demikian, pengelolaan kawasan kepesisiran di Kabupaten Buton Selatan pada kondisi sekarang secara umum bersifat cukup berkelanjutan. Oleh karena itu, peningkatan nilai keberlanjutan pengelolaan perlu ditingkatkan melalui upaya perbaikan 15 komponen kunci yang terlibat.

Skenario konservatif-pesimistik adalah skenario yang melibatkan perbaikan terhadap komponen-komponen kunci pada level minimum. Efisiensi biaya perbaikan menjadi pertimbangan dalam upaya perbaikan. Pada tingkat kabupaten, komponen-komponen kunci yang dapat diperbaiki intensitas konversi lahan perikanan, pemberdayaan masyarakat dalam kegiatan perikanan, penggunaan teknologi dalam budidaya, pariwisata, dan insentif investasi.

Skenario moderat-optimistik adalah skenario yang melibatkan upaya perbaikan sekitar setengah $(50 \%)$ dari seluruh komponen kunci (komponen yang sensitif). Pengelolaan kawasan kepesisiran pada skenario ini dilakukan secara bertahap sesuai dengan biaya yang tersedia sehingga pencapaian target pengelolaan membutuhkan waktu yang sangat lama. Konsekuensi dari skenario ini adalah tidak memungkinkan melakukan upaya-upaya yang cepat terhadap kendala-kendala yang dialami oleh beberapa komponen, sementara komponen-komponen tersebut berpengaruh terhadap komponen lainnya. Sebagai contoh, penyediaan akses tidak dapat dilakukan dalam waktu singkat, sehingga berpengaruh pada kegiatankegiatan perekonomian lainnya.

Sementara, pada skenario progresifoptimistik, seluruh komponen diupayakan dalam kondisi yang memadai. Skenario tersebut bersifat jangka panjang dan memerlukan dukungan pembiayaan yang memadai. Oleh karena itu, skema penerapannya di lakukan dalam tiga tahapan, yaitu jangka pendek, jangka menengah dan jangka panjang. Penerapan pada jangka pendek dititikberatkan pada perbaikan komponen-komponen kunci yang harus dilakukan secepatnya. Sementara jangka menengah dan jangka panjang diutamakan pada penyelesaian masalah terhadap komponen penunjang pengelolaan kawasan kepesisiran. Keberhasilan skenario progresifoptimistik sangat bergantung pada komitmen yang kuat serta keseriusan dari pemerintah daerah.

Kemungkinan untuk mengimplementasikan tiga skenario pengelolaan lingkungan di wilayah kepesisiran Kabupaten Buton Selatan selanjutnya dinilai menggunakan pendekatan penilaian ilmiah (scientific judgement) seperti yang dilakukan juga oleh Bohari (2010) dan Supardi et al., 
(2017). Analisis kemungkinan implementasi ke tiga skenario diurutkan dalam Tabel 5 dari yang paling besar kemungkinannya hingga paling kecil. Berdasarkan Tabel 5, skenario moderat-optimistik berada pada peringkat 1 , disusul secara berurut oleh senario progresifoptimistic dan konservatif-optimistik. Oleh karena itu, skenario tersebut dipandang sebagai skema yang paling mungkin untuk diimpelentasikan dalam pengelolaan wilayah kepesisiran berkelanjutan di Kabupaten Buton Selatan.

Tabel 5. Peringkat kemungkinan implementasi skenario pengelolaan kawasan kepesisiran di Kabupaten Buton Selatan

\begin{tabular}{lc}
\hline \multicolumn{1}{c}{ Skenario } & $\begin{array}{c}\text { Peringkat } \\
\text { Kemungkian }\end{array}$ \\
\hline Moderat-Optimistik & 1 \\
Progresif-Optimistik & 2 \\
Konservatif-Optimistik & 3 \\
\hline
\end{tabular}

Sumber: Hasil Analisis

Namun demikian, penilaian-penilaiain yang lebih spesifik terhadap upaya pengelolaan kawasan kepesisiran berkelanjutan di Kabupaten Buton Selatan perlu dilakukan. Penilaian lanjutan dapat dilakukan dengan membagi wilayah kepesisiran Kabupaten Buton Selatan kedalam beberapa segmen mengingat kondisi kawasan pesisir di Kabupaten Buton Selatan cukup luas dan panjang. Dengan demikian, pengelolaan diharapkan dapat berjalan sesuai kondisi real di lapangan.

\section{SIMPULAN}

Skenario moderat-optimistik merupakan skenario paling mungkin untuk diimplementasikan dalam upaya pengelolaan lingkungan wilayah kepesisiran berkelanjutan di Kabupaten Buton Selatan. Skenario tersebut menunjukkan peningkatan pada produksi industri perikanan. Pengelolaan pada skenario moderatoptimistik dilakukan secara bertahap karena pertimbangan biaya sehingga diperlukan waktu yang lama untuk pencapaian target pengelolaannya. Selain itu, skenario tersebut juga mengakomodir upaya-upaya perbaikan sesegera mungkin terhadap permasalahan pada beberapa komponen sehingga pengaruh komponen-komponen tersebut terhadap komponen lainnya dapat dimimalkan.

Komponen-komponen yang diidentifikasi untuk segera diperbaiki diantaranya adalah penyediaan sarana dan prasarana infrastruktur (jalan) dan perlindungan fisik habitat karena berdampak pada peningkatan pendapatan masyarakat pesisir.

\section{DAFTAR PUSTAKA}

Barbier, E. B. (2015). Climate change impacts on rural poverty in lowelevation coastal zones. Estuarine, Coastal and Shelf Science, 165, A1A13.

Bohari, R. (2010). Model Kebijakan Pengelolaan Wilayah Pesisir Makassar Sulawesi Selatan. Bogor: Institut Pertanian Bogor.

Bourgeois, R., \& Jesus, F. (2004). Participatory Prospective Analysis: Exploring and anticipating Challenges with Stakehoders (No. 1437-2016118895), UNESCAP-CAPSA. Capsa No.46.

Clark, J. R. (1997). Coastal zone management for the new century. Ocean and Coastal Management, 37(2), 191-216.

Dahuri, R. (2001). Pengelolaan Ruang Wilayah Pesisir Dan Lautan Seiring Dengan Pelaksanaan Otonomi Daerah. Mimbar: Jurnal Sosial Dan Pembangunan, 17(2), 139-171.

Fan, D., Xu, J., Wu, Y., \& Lee, G. (2019). Coastal environmental changes under increasing anthropogenic impacts: an introduction. Anthropocene Coasts, 2(1), $\mathrm{v}-\mathrm{xii}$. 
Hadi, T. A., Giyanto, Prayudha, B., Hafitz, M., Budiyanto, A., \& Suharsono. (2018). Status Terumbu Karang Indonesia. Jakarta: Puslit Oseanografi - LIPI.

Joseph, K. A., \& Balchand, A. N. (2000). The application of coastal regulation zones in coastal management Appraisal of Indian experience. Ocean and Coastal Management, 43(6), 515526.

Kantamaneni, K., Phillips, M., Thomas, T., \& Jenkins, R. (2018). Assessing coastal vulnerability: Development of a combined physical and economic index. Ocean and Coastal Management, 158(March), 164-175.

Lee, M. T., Wu, C. C., Ho, C. H. ., \& Liu, W. H. (2014). Towards marine spatial planning in Southern Taiwan. Sustainability, 6(12), 8466-8484.

MacDonald, R. B. (2005). Managing Marine Misbehavior: Good Science, Good Policy, Bad Human. Journal of International Affairs, 59 (1), 273-281.

Marfai, M. A., \& King, L. (2007). Monitoring land subsidence in Semarang, Indonesia. Environmental Geology, 53(3), 651-659.

Marfai, M. A., \& King, L. (2008). Tidal inundation mapping under enhanced land subsidence in Semarang, Central Java Indonesia. Natural Hazards, 44(1), 93-109.

Roza, E. (2017). Maritim Indonesia, Kemewahan Yang Luar Biasa. Jakarta: Kementrian Kelautan dan Perikanan RI.

Sanchez-Cabez, J.-A., \& Druffel, E. (2009). Environmental records of anthropogenic impacts on coastal ecosystems: An introduction. Marine Pollution Bulletin, 59, 87-90. Retrieved from https://creativecommons.org/licenses/by 14.0.

Spalding, M., McIvor, A., Tonneijck, F., Tol, S., \& van Eijk, P. (2014). Bakaus for coastal defence. Guidelines for coastal managers \& policy makers. Wetlands International and The Nature Conservancy.

Sudirman. (2008). Warning Atas Kerusakan Hutan Bawah Laut. Surat Kabar Identitas Unhas. Retrieved from http://repository.unhas.ac.id/handle/123 456789/885.

Supardi, S., Hariyadi, S., \& Fahrudin, A. (2017). Analisis Keberlanjutan Pembangunan Kota Tepian Pantai (Studi Kasus: Kota Baubau Provinsi Sulawesi Tenggara). Jurnal Wilayah Dan Lingkungan, 5(3), 188.

Uncles, R. J., Hooper, T., Stephens, J. A., \& Harris, C. (2018). Seasonal variability of turbidity, salinity, temperature and suspended chlorophyll in a strongly tidal sub-estuary: The Lynher Marine Conservation Zone. Estuarine, Coastal and Shelf Science, 212(July), 253-264.

Waluyo, A. (2014). Secara Terpadu Yang Berbasis Masyarakat (Studi Kasus Pulau Raas Kabupaten Sumenep Madura). Jurnal Kelautan, 7(2), 75-85.

Widyaningrum, G. L. (2019). Lebih Dari 50\% Hutan Bakau di Indonesia Hilang, Apa Penyebabnya? National Geographic Indonesia. Retrieved from https://nationalgeographic.grid.id/read/1 31739246.

Xu, X., Li, X., Chen, M., Li., X., Duan, X., Zhu, G., Ma, Z. (2016). Land-oceanhuman interactions in intensively developing coastal zone: Demonstration of case studies. Ocean and Coastal Management, 133, 28-36. 